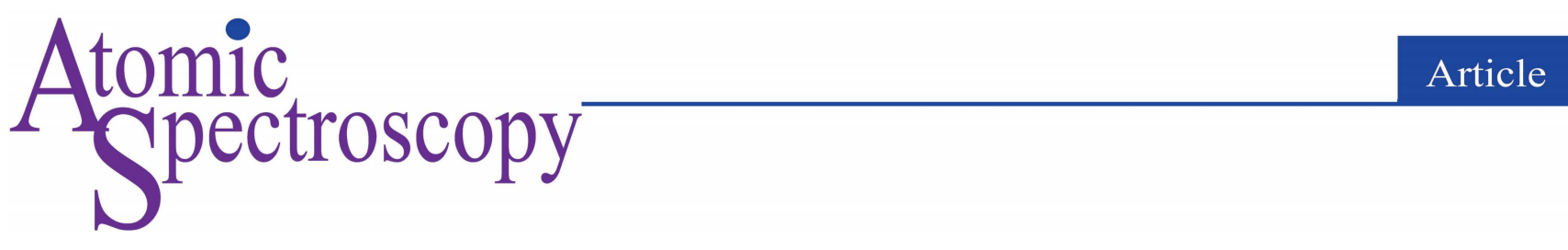

\title{
In situ Rb-Sr Dating of Lunar Meteorites Using Laser Ablation MC-ICP-MS
}

\author{
Wen Zhang, ${ }^{\text {a,* }}$ Zaicong Wang, ${ }^{\text {a }}$ Zhaochu Hu, ${ }^{\text {a }}$ Qi He, ${ }^{\text {a }}$ Yiheng Li, ${ }^{\text {a }}$ Yangtong Feng, ${ }^{\text {a }}$ \\ Hong Liu, ${ }^{\mathbf{a}}$ and Xiaojing Zhang ${ }^{\mathrm{b}}$ \\ ${ }^{a}$ State Key Laboratory of Geological Processes and Mineral Resources, China University of Geosciences, Wuhan 430074, P.R. China \\ ${ }^{\mathrm{b}}$ Qianxuesen Laboratory of Space Technology, China Academy of Space Technology, Beijing 100029, P.R. China
}

Received: November 28, 2021; Revised: January 27, 2022; Accepted: January 27, 2022; Available online: January $27,2022$.

DOI: $10.46770 / A S .2022 .007$

ABSTRACT: Plagioclase, pyroxene and glass are the main component phases of different planetary materials. In situ Rb-Sr dating of these common phases thus would represent the timing of magmatic differentiation, effectively complementary to the rare, tiny U-Pb bearing phases that only form at a late stage. In this study, we selected lunar meteorites as examples to establish an in situ $\mathrm{Rb}-\mathrm{Sr}$ dating method where plagioclase, pyroxene, ilmenite, and glasses were the laser-ablation (LA) targets. The accuracy of ${ }^{87} \mathrm{Sr} /{ }^{86} \mathrm{Sr}$ and ${ }^{87} \mathrm{Rb} /{ }^{86} \mathrm{Sr}$ measured by LA-MC-ICP-MS was better than $0.2 \%$ and $3 \%$, respectively, for samples with an ${ }^{87} \mathrm{Rb} /{ }^{86} \mathrm{Sr}$ ratio lower than 1 . However, we found that the distributions of $\mathrm{Rb}$ and $\mathrm{Sr}$ in the natural materials were heterogeneous at the micrometer scale, leading to inaccurate ${ }^{87} \mathrm{Rb} /{ }^{86} \mathrm{Sr}$ ratio correction when calculated by normal data reduction methods. A new data reduction strategy of the smallest unit of isochron age (SUIA) was developed. Using the SUIA, the Rb-Sr isochron age of $2984 \pm 43 \mathrm{Ma}$ and $3149 \pm 20$ Ma was obtained for two lunar meteorites (NWA 10597 and NWA 6950, respectively). These results are identical within $1-2 \%$ deviation relative to the $\mathrm{U}-\mathrm{Pb}$ dating ages for baddeleyite and apatite using SIMS. The present method may have broad applicability for determining the $\mathrm{Rb}$-Sr isochron ages of other planetary samples.

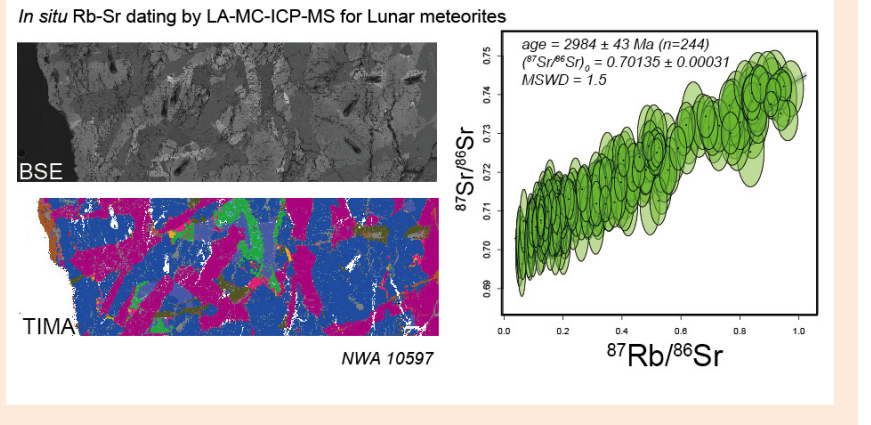

\section{INTRODUCTION}

The $\mathrm{Rb}$-Sr decay system was one of the first and extensively used methods for geochronology studies. ${ }^{1,2}{ }^{87} \mathrm{Rb}$ decays to ${ }^{87} \mathrm{Sr}$ by $\beta$ decay with a decay constant of $1.393 \pm 0.004 \times 10^{-11}$ per year. $^{3}$ An advantage of the $\mathrm{Rb}-\mathrm{Sr}$ system is the relatively large variation of the $\mathrm{Rb} / \mathrm{Sr}$ ratio in rocks, largely due to the difference in the geochemical properties between $\mathrm{Rb}$ and $\mathrm{Sr}$. The system has been successfully applied to igneous rocks, metamorphic rocks, and sulfide minerals in ore deposits. ${ }^{4-6}$

The accurate determination of ${ }^{87} \mathrm{Sr} /{ }^{86} \mathrm{Sr}$ and ${ }^{87} \mathrm{Rb} /{ }^{86} \mathrm{Sr}$ for $\mathrm{Rb}-\mathrm{Sr}$ dating is generally conducted by thermal ionization mass spectrometry (TIMS) or multicollector inductively coupled plasma mass spectrometry (MC-ICP-MS) in combination with a complex chemical purification process and isotopic spiking. In recent years, an in situ $\mathrm{Rb}$-Sr dating method was developed based on laser ablation inductively coupled plasma massspectrometry/mass-spectrometry (LA-ICP-MS/MS). ${ }^{7-10}$ ICP$\mathrm{MS} / \mathrm{MS}$ can effectively resolve the isobaric interference of ${ }^{87} \mathrm{Rb}$ on ${ }^{87} \mathrm{Sr}$ by using a reaction/collision cell to separate $\mathrm{Rb}$ and $\mathrm{Sr}^{11}$ Hence, LA-ICP-MS/MS allows for targeted analysis at the micrometer scale, making in situ $\mathrm{Rb}$-Sr dating of minerals possible. The most popular ICP-MS/MS instrument currently in use is the Agilent 8800 , which is a quadrupole ICP-MS/MS. However, recently, the Vienna MC-ICP-MS/MS was introduced (manufactured by Thermo Scientific) and used by Craig et al. ${ }^{12}$ for in situ $\mathrm{Rb}-\mathrm{Sr}$ dating, combined with a laser ablation system. During the measurements by traditional (MC-)ICP-MS without the reaction/collision cell, the ${ }^{87} \mathrm{Rb}$ interference is corrected by monitoring ${ }^{85} \mathrm{Rb}$ and using the natural ${ }^{87} \mathrm{Rb} /{ }^{85} \mathrm{Rb}$ ratio of 0.38571 . 


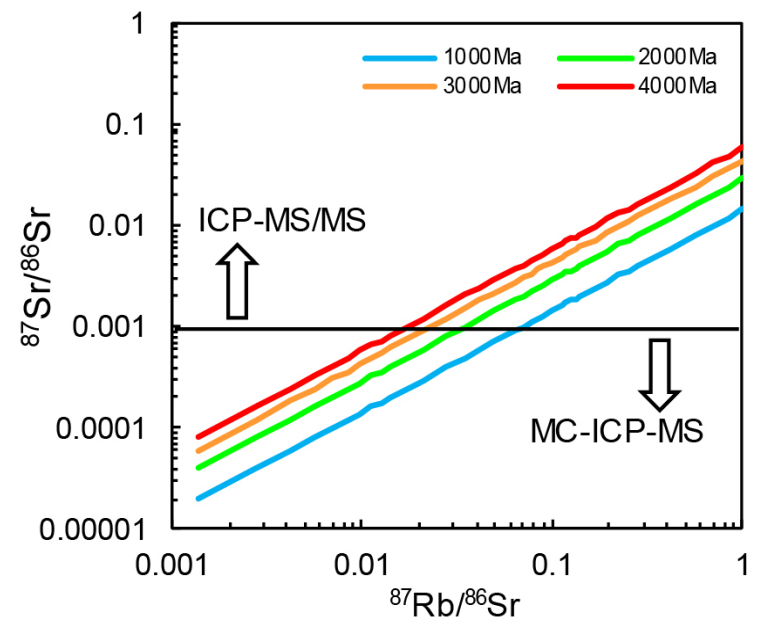

Fig. 1 The modelled effects of variable ${ }^{87} \mathrm{Rb} /{ }^{86} \mathrm{Sr}$ ratios on radiogenic ${ }^{87} \mathrm{Sr} /{ }^{86} \mathrm{Sr}$ at different crystallization ages (1000 Ma, $2000 \mathrm{Ma}, 3000 \mathrm{Ma}$, $4000 \mathrm{Ma}$ ). The black line represents an accumulated value of 0.001 for ${ }^{87} \mathrm{Sr} /{ }^{86} \mathrm{Sr}$, which can be resolved using the latest developed LA-MC-ICPMS instrument, but is difficult to resolve with the quadrupole ICP-MS/MS.

This correction approach, however, may lead to inaccurate results when the concentration of the interfering element (in this case, $\mathrm{Rb}$ ) is too high. ${ }^{13}$

The formation ages of lunar materials, including lunar meteorites and lunar samples collected during space missions, are critical for establishing the evolution history of the Earth-Moon system. ${ }^{14,15}$ Whole rock / mineral solution $\mathrm{Rb}$-Sr isotope data have been obtained to determine the age of lunar meteorites, ${ }^{16,17}$ but these rarely involved the micro-analysis method. The microanalysis technique requires only a tiny amount of sample and, more importantly, can achieve high-spatial resolution. In situ U$\mathrm{Pb}$ dating has been widely used for such purposes, but this method targets $\mathrm{U}-\mathrm{Pb}$ rich phases, such as baddeleyite and apatite, which mainly form at the late stage of magmatic differentiation. ${ }^{18,19}$ However, most meteorites are ultramafic or mafic in composition and $\mathrm{U}-\mathrm{Pb}$ rich phases therein are rare or, if any, are tiny.

Instead, plagioclase, pyroxene and glass are the main constituent phases of different planetary samples. In situ dating of these widely present phases is significant for planetary magmatism, and the Rb-Sr system would be ideal and represent the timing of magma differentiation. More importantly, these minerals in meteorites generally display low but highly variable $\mathrm{Rb} / \mathrm{Sr}$ ratios. The variable $\mathrm{Rb} / \mathrm{Sr}$ ratios in plagioclase, pyroxene and glasses could be suitable for isochron. However, the low $\mathrm{Rb} / \mathrm{Sr}$ minerals do not accumulate significant radiogenic ${ }^{87} \mathrm{Sr}$, even in old meteorites. Fig. 1 shows the radiogenic ${ }^{87} \mathrm{Sr} /{ }^{86} \mathrm{Sr}$ ratios from different ${ }^{87} \mathrm{Rb} /{ }^{86} \mathrm{Sr}$ ratios. The 0.001 change of ${ }^{87} \mathrm{Sr} /{ }^{86} \mathrm{Sr}$ caused by ${ }^{87} \mathrm{Rb}$ decay can be identified by using the modern LA-MC-ICPMS method, but it is difficult with quadrupole ICP-MS/MS.
In this study, we investigate the potential of in situ $\mathrm{Rb}$-Sr dating by LA-MC-ICP-MS of lunar meteorites. The accuracy and precision of ${ }^{87} \mathrm{Sr} /{ }^{86} \mathrm{Sr}$ and ${ }^{87} \mathrm{Rb} /{ }^{86} \mathrm{Sr}$ are assessed in detail through repeated analysis of 14 reference materials. Plagioclases, pyroxenes, ilmenites, and glasses in two lunar meteorites (NWA 10597 and NWA 6950) were measured by LA-MC-ICP-MS. We developed a new data reduction method to resolve the heterogeneous distribution of $\mathrm{Rb}$ and $\mathrm{Sr}$ in natural minerals. The final $\mathrm{Rb}-\mathrm{Sr}$ isochron age of the two meteorites was found to be consistent with the results obtained using other radiogenic dating systems.

\section{EXPERIMENTAL}

Instrumentation. In situ Sr isotope analyses were performed with the NEPTUNE Plus MC-ICP-MS instrument (Thermo Fisher Scientific, Bremen, Germany), which was connected to a femtosecond laser ablation system located at the State Key Laboratory of Geological Processes and Mineral Resources (GPMR), China University of Geosciences, Wuhan. The NEPTUNE Plus, which is a double focusing MC-ICP-MS, was equipped with seven fixed electron multiplier ICs and nine Faraday cups fitted with $10^{11} \Omega$ resistors. The Faraday collector configuration of the mass system was composed of an array from $\mathrm{L} 4$ to $\mathrm{H} 3$ to monitor $\mathrm{Kr}, \mathrm{Rb}, \mathrm{Er}, \mathrm{Yb}$, and $\mathrm{Sr}$ (Table 1). The femtosecond laser ablation system is a NWR Femto ${ }^{\text {UC }}$ femtosecond system (New Wave Research, Fremont, CA, USA), which consisted of a $300 \mathrm{fs} \mathrm{Yb}$ : KGW femtosecond laser amplifier (PHAROS, Light Conversion Ltd., Vilnius, Lithuania) with a wavelength of $257 \mathrm{~nm}$. The laser ablation was equipped with a two-volume cell, which has the constant distance between the laser

Table 1 Summary of the operating parameters for LA-MC-ICP-MS

\begin{tabular}{lc}
\hline MC-ICP-MS (Neptune Plus) & Parameters \\
\hline RF power & $1250 \mathrm{~W}$ \\
Cool gas flow & $16.0 \mathrm{~L} \mathrm{~min}^{-1}$ \\
Auxiliary gas flow & $0.80 \mathrm{~L} \mathrm{~min}^{-1}$ \\
Helium carrier gas flow & $0.90 \mathrm{~L} \mathrm{~min}^{-1}$ \\
Nitrogen gas flow & $12 \mathrm{ml} \mathrm{min}{ }^{-1}$ \\
Interface cones & $\mathrm{X}$ skimmer cone + Jet sample \\
Instrument resolution & cone \\
Block number & $\sim 400($ low mode $)$ \\
Cycles of each block & 1 \\
Integration Time (s) & 120 \\
Cup-configuration & $0.524 \mathrm{~s}$ \\
& $\mathrm{~L} 4\left({ }^{83} \mathrm{Kr}\right), \mathrm{L} 3\left({ }^{167} \mathrm{Er}{ }^{++}\right), \mathrm{L} 2\left({ }^{84} \mathrm{Sr}\right)$, \\
Laser ablation system & $\mathrm{L} 1\left({ }^{85} \mathrm{Rb}\right), \mathrm{C}\left({ }^{86} \mathrm{Sr}\right), \mathrm{H} 1\left({ }^{173} \mathrm{Yb}{ }^{++}\right)$, \\
Laser type & $\mathrm{H} 2\left({ }^{87} \mathrm{Sr}\right)$, and H3 $\left({ }^{88} \mathrm{Sr}\right)$. \\
Wavelength & Parameters \\
Pulse length & $\mathrm{Yb}: \mathrm{YAG} \mathrm{femtosecond} \mathrm{laser}$ \\
Energy density & $257 \mathrm{~nm}$ \\
Spot size & $300 \mathrm{fs}$ \\
Laser frequency & $60 \%$ \\
Scan speed & $50-60 \mu \mathrm{m}$ \\
& $10-30 \mathrm{~Hz}$ \\
& $2-6 \mu \mathrm{m} \mathrm{s}{ }^{-1}$ \\
\hline
\end{tabular}


Table 2 The measurement results of ${ }^{87} \mathrm{Sr} /{ }^{86} \mathrm{Sr}$ and ${ }^{87} \mathrm{Rb} /{ }^{86} \mathrm{Sr}$ by LA-MC-ICP-MS for 14 reference materials

\begin{tabular}{|c|c|c|c|c|c|c|c|c|c|c|c|c|}
\hline \multirow[b]{2}{*}{ Reference materials } & \multicolumn{5}{|c|}{ Recommended values } & \multicolumn{7}{|c|}{ Measured values by LA-MC-ICP-MS } \\
\hline & $\mathbf{R b}\left(\mu \mathrm{g} \mathrm{g}^{-1}\right)$ & $\operatorname{Sr}\left(\mu \mathrm{g} \mathbf{g}^{-1}\right)$ & ${ }^{87} \mathbf{R b} /{ }^{86} \mathrm{Sr}$ & ${ }^{87} \mathbf{S r} /{ }^{86} \mathbf{S r}$ & uncertainty & ${ }^{87} \mathbf{R b} /{ }^{86} \mathrm{Sr}$ & 2SD & $\begin{array}{c}\text { Rel. error } \\
(\%) *\end{array}$ & ${ }^{87} \mathrm{Sr} /{ }^{86} \mathrm{Sr}$ & 2SD & $\begin{array}{c}\text { Rel. error } \\
\text { (\%o) \# }\end{array}$ & $\mathbf{N}$ \\
\hline NIST610 & 415 & 521 & 2.320 & 0.70970 & 0.00002 & 2.251 & 0.015 & -2.97 & 0.69872 & 0.00035 & -15.47 & 3 \\
\hline NIST612 & 31.8 & 78.4 & 1.181 & 0.70906 & 0.00002 & 1.205 & 0.004 & 2.02 & 0.70313 & 0.00126 & -8.37 & 3 \\
\hline BCR-2G & 47.0 & 342 & 0.400 & 0.70500 & 0.00001 & 0.402 & 0.020 & 0.50 & 0.70498 & 0.00029 & -0.04 & 12 \\
\hline BHVO-2G & 9.18 & 396 & 0.068 & 0.70347 & 0.00001 & 0.066 & 0.004 & -1.99 & 0.70348 & 0.00026 & 0.01 & 30 \\
\hline TB-1G & 142 & 1352 & 0.306 & 0.70558 & 0.00002 & 0.311 & 0.001 & 1.58 & 0.70551 & 0.00007 & -0.10 & 3 \\
\hline NKT-1G & 30.7 & 1195 & 0.075 & 0.70351 & 0.00002 & 0.073 & 0.000 & -3.14 & 0.70357 & 0.00008 & 0.09 & 5 \\
\hline ATHO-G & 65.3 & 94.1 & 2.021 & 0.70327 & 0.00002 & 2.080 & 0.238 & 2.89 & 0.68598 & 0.00460 & -24.58 & 4 \\
\hline KL2-G & 8.70 & 356 & 0.071 & 0.70357 & 0.00002 & 0.070 & 0.005 & -2.08 & 0.70357 & 0.00021 & 0.01 & 7 \\
\hline ML3B-G & 5.80 & 312 & 0.054 & 0.70385 & 0.00001 & 0.055 & 0.002 & 1.95 & 0.70377 & 0.00037 & -0.11 & 11 \\
\hline StHs6/80-G & 30.7 & 482 & 0.186 & 0.70354 & 0.00004 & 0.182 & 0.013 & -2.01 & 0.70368 & 0.00027 & 0.20 & 6 \\
\hline T1-G & 79.7 & 284 & 0.817 & 0.71014 & 0.00000 & 0.833 & 0.038 & 1.89 & 0.71007 & 0.00044 & -0.10 & 28 \\
\hline YG4301 & 0.670 & 1058 & 0.002 & 0.70343 & 0.00002 & & & & 0.70335 & 0.00016 & -0.10 & 18 \\
\hline YY12-01 & 0.090 & 192 & 0.001 & 0.70358 & 0.00001 & & & & 0.70349 & 0.00035 & -0.12 & 8 \\
\hline HNB09 & 0.008 & 50.9 & 0.000 & 0.70374 & 0.00001 & & & & 0.70368 & 0.00055 & -0.08 & 10 \\
\hline
\end{tabular}

* Rel. error $(\%)$ is relative error and $=($ measured value $/$ reference value -1$) \times 100 ; \quad \#$ Rel. error $(\%)=($ measured value $/$ reference value -1$) \times 1000$

ablation position with the aerosol extraction position. Helium gas was filled into the ablation cell, while argon was mixed into the sample-out line downstream from the ablation chamber before entering the torch. A signal-smoothing device was used downstream from the sample cell, which significantly reduced the short-term variability of the signal. ${ }^{20}$ Details of the instrumental operating conditions and measurement parameters are summarized in Table 1.

Samples. The well-characterized reference materials (RMs) from the National Institute of Standards and Technology (NIST, USA) glasses (610 and 612), the United States Geological Survey (USGS) RMs (BCR-2G (basalt), BHVO-2G (basalt), NKT-1G (nephelinite), TB-1G (basalt)), and the Max Planck Institute (MPIDING, Germany) glasses (ATHO-G (rhyolite), KL2-G (basalt), ML3B-G (basalt), StHs6/80-G (andesite), T1-G (quartz-diorite)) were used as the external standards for measurement of the ${ }^{87} \mathrm{Rb} /{ }^{86} \mathrm{Sr}$ ratio and as unknown samples for measurement of the ${ }^{87} \mathrm{Sr} /{ }^{86} \mathrm{Sr}$ ratio. Two natural clinopyroxenes (NHB and YY12-01) and one natural anorthite (YG4301) were used as the unknown samples to evaluate the data quality of ${ }^{87} \mathrm{Sr} /{ }^{86} \mathrm{Sr}$. The recommended values of the ${ }^{87} \mathrm{Rb} /{ }^{86} \mathrm{Sr}$ and ${ }^{87} \mathrm{Sr} /{ }^{86} \mathrm{Sr}$ ratios for the $\mathrm{RMs}$ are listed in Table 2. The mass fractions of $\mathrm{Sr}$ and $\mathrm{Rb}$ and the ${ }^{87} \mathrm{Sr} /{ }^{86} \mathrm{Sr}$ ratios in the reference glasses are compiled from the literature. ${ }^{13,21-28}$

Two different lunar meteorites (NWA 10597 and NWA 6950) were analyzed for $\mathrm{Rb}$-Sr isotopes. NWA 10597 is a low-Ti mare basaltic lunar meteorite and consists mostly of mm-sized pyroxene and plagioclase, with minor olivine, spinel, ilmenite, phosphates, silica, and trace Zr-rich minerals, such as baddeleyite, zirconolite and tranquillityite. The in situ U-Pb analyses of baddeleyite and apatite using SIMS reveal a mutually consistent age of $\sim 3.0 \mathrm{Ga}{ }^{29}$, ${ }^{30}$ NWA 6950 is a $224.5 \mathrm{~g}$ meteorite that was found in Morocco in 2000 and has been identified as a lunar olivine gabbro. NWA 6950 is mainly composed of olivine and pyroxene with minor plagioclase. Additionally, chromite, ilmenite, phosphate, baddeleyite, K-feldspar, troilite, and $\mathrm{Fe}-\mathrm{Ni}$ metal occur as accessory phases. The in situ U-Pb dating of baddeleyite and phosphate in NWA 6950 implies two crystallization ages: $3187 \pm$ 18 and $3120 \pm 18 \mathrm{Ma}^{31}$

LA-MC-ICP-MS measurement and data reduction. Detailed analytical procedures for $\mathrm{Sr}$ isotopic composition are described by Zhang et al. (2018). ${ }^{13}$ In summary, the combination of highsensitivity X-skimmer cone and JET-sample cone was employed, and the mass spectrometer was operated in low mass resolution mode. A small amount of $\mathrm{N}_{2}\left(12 \mathrm{~mL} \mathrm{~min}^{-1}\right)$ was added to the carrier gas flow by using a simple $\mathrm{Y}$ connector behind the signalsmoothing device. NIST 610 was used to optimize the instrumental parameters, including the $\mathrm{He}$ and $\mathrm{Ar}$ gas flow rates, the torch position, the RF power setting, and the source lens settings for maximum sensitivity and optimum peak flatness. The routine data acquisition consisted of one block of 120 cycles ( $0.524 \mathrm{~s}$ integration time per cycle), with the first 30 cycles for background collection (no laser ablation) and the remaining 90 cycles for signal collection. Note that only $60-70$ cycles were finally used to calculate the isotope ratios; the cycles at the beginning and at the end of the laser ablation were discarded. The samples were measured with different laser ablation parameters 

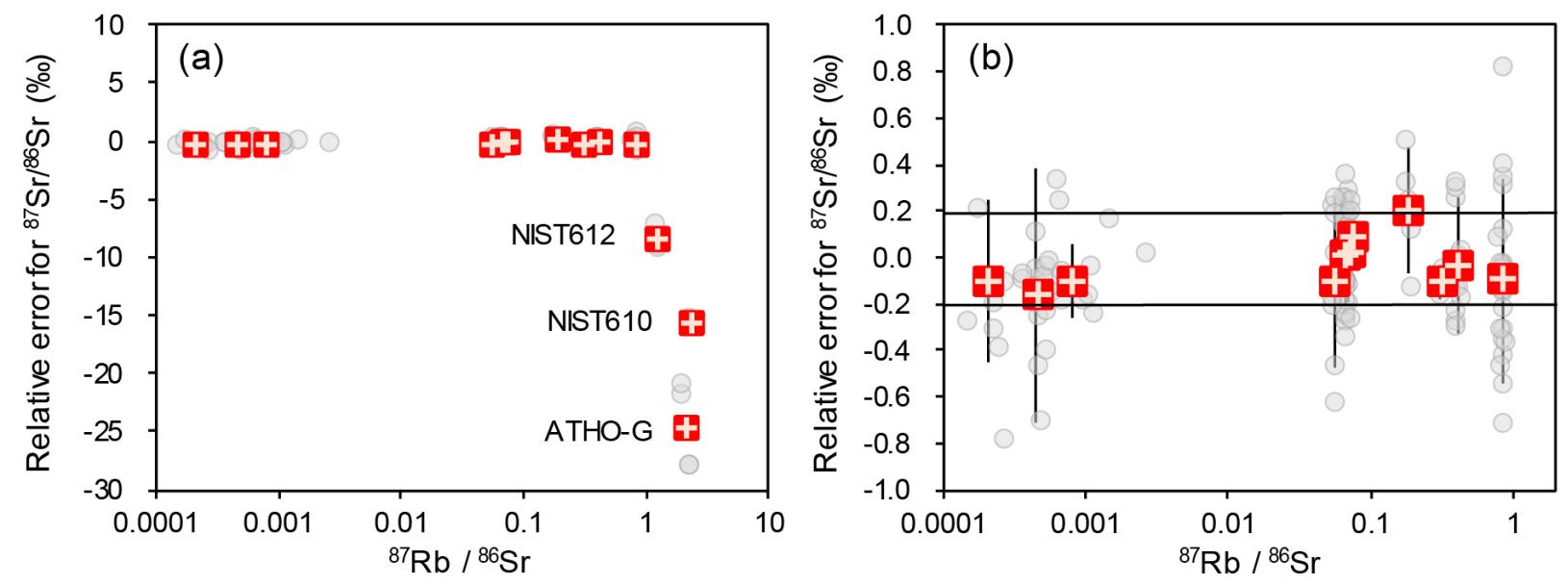

Fig. 2 The repeated measurement results of ${ }^{87} \mathrm{Sr} /{ }^{86} \mathrm{Sr}$ in 14 reference materials by LA-MC-ICP-MS (a), and part of reference materials with ${ }^{87} \mathrm{Rb} /{ }^{86} \mathrm{Sr}$ lower than 1 (b). The red crosses represent the average values with uncertainty of 2SD. Gray circles represent the analytical results from individual runs.
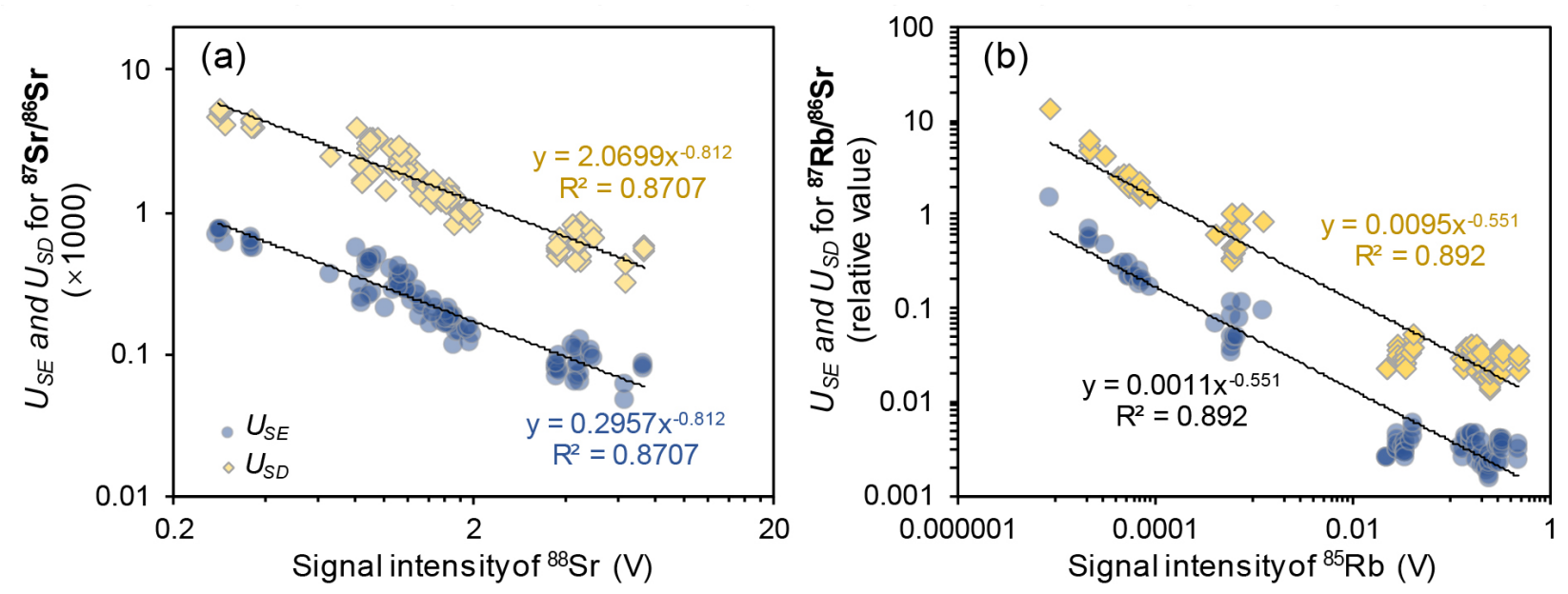

Fig. 3 The relationship between ${ }^{88} \mathrm{Sr}$ signal intensity and the $U_{S E}$ and $U_{S D}$ of ${ }^{87} \mathrm{Sr} /{ }^{86} \mathrm{Sr}$ (a) and between ${ }^{85} \mathrm{Rb}$ signal intensity and the $U_{S E}$ and $U_{S D}$ of ${ }^{87} \mathrm{Rb} /{ }^{86} \mathrm{Sr}$ (b). Note that the $U_{S E}$ and $U_{S D}$ of ${ }^{87} \mathrm{Sr} /{ }^{86} \mathrm{Sr}$ are multiplied by 1000 . The $U_{S E}$ and $U_{S D}$ of ${ }^{87} \mathrm{Rb} /{ }^{86} \mathrm{Sr}$ are relative values $=\left(U_{S E}\right.$ or $\left.U_{S D}\right) /$ the average value. All data are from the 14 reference materials.

based on the $\mathrm{Sr}$ concentration in the samples. The detailed setup parameters of the laser system and the MC-ICP-MS are listed in Table 1. The data reduction for LA-MC-ICP-MS analysis was conducted with the ISO-Compass software. ${ }^{32}$ The interference correction strategy was the same as reported by Zhang et al. (2018). ${ }^{13}$ The regions of integration for both the gas background and the sample were selected first. Following background correction, which removes the background $\mathrm{Kr}^{+}$signals, no additional $\mathrm{Kr}$ peak stripping was applied. The interferences were corrected by using the following sequence: (a) the interferences of ${ }^{168} \mathrm{Er}^{++}$on ${ }^{84} \mathrm{Sr},{ }^{170} \mathrm{Er}^{++}$and ${ }^{170} \mathrm{Yb}^{++}$on ${ }^{85} \mathrm{Rb},{ }^{172} \mathrm{Yb}^{++}$on ${ }^{86} \mathrm{Sr}$, and ${ }^{174} \mathrm{Yb}^{++}$on ${ }^{87} \mathrm{Sr}$ were corrected based on the measured signal intensities of ${ }^{167} \mathrm{Er}^{++},{ }^{173} \mathrm{Yb}^{++},{ }^{84,}{ }^{86-88} \mathrm{Sr}$ and ${ }^{85} \mathrm{Rb}$ and the natural isotope ratios of $\mathrm{Er}$ and $\mathrm{Yb}$; (b) the isobaric interference of ${ }^{87} \mathrm{Rb}$ on ${ }^{87} \mathrm{Sr}$ was corrected by monitoring the ${ }^{85} \mathrm{Rb}$ signal intensity and a user-specified ${ }^{87} \mathrm{Rb} /{ }^{55} \mathrm{Rb}$ ratio using the exponential law for mass bias. The user-specified ${ }^{87} \mathrm{Rb} /{ }^{85} \mathrm{Rb}$ ratio was calculated by measuring some reference materials with a known ${ }^{87} \mathrm{Sr} /{ }^{86} \mathrm{Sr}$ ratio. Following the interference corrections, mass fractionation of the Sr isotopes was corrected by assuming ${ }^{88} \mathrm{Sr} /{ }^{86} \mathrm{Sr}=8.375209^{33}$ and applying the exponential law. ${ }^{34}$

The ${ }^{87} \mathrm{Rb} /{ }^{86} \mathrm{Sr}$ ratio was calculated using the ${ }^{85} \mathrm{Rb}$ and ${ }^{88} \mathrm{Sr}$ signals and the ${ }^{87} \mathrm{Rb} /{ }^{85} \mathrm{Rb}$ of 0.385706 and ${ }^{86} \mathrm{Sr} /{ }^{88} \mathrm{Sr}$ of 0.119351 . External calibration was used to correct the elemental fractionation between $\mathrm{Rb}$ and $\mathrm{Sr}$. A series of reference glasses was analyzed to provide an average correction factor. Then the average factor was used for the samples and reference materials. This data reduction procedure was also employed using the ISO-Compass software.

Based on the LA-MC-ICP-MS method described above, ${ }^{87} \mathrm{Sr} /{ }^{86} \mathrm{Sr}$ and ${ }^{87} \mathrm{Rb} /{ }^{86} \mathrm{Sr}$ in different glasses, clinopyroxenes and anorthite were measured to evaluate the data quality. Fig. 2 shows the relative error of ${ }^{87} \mathrm{Sr} /{ }^{86} \mathrm{Sr}$ in the reference materials (the relative 

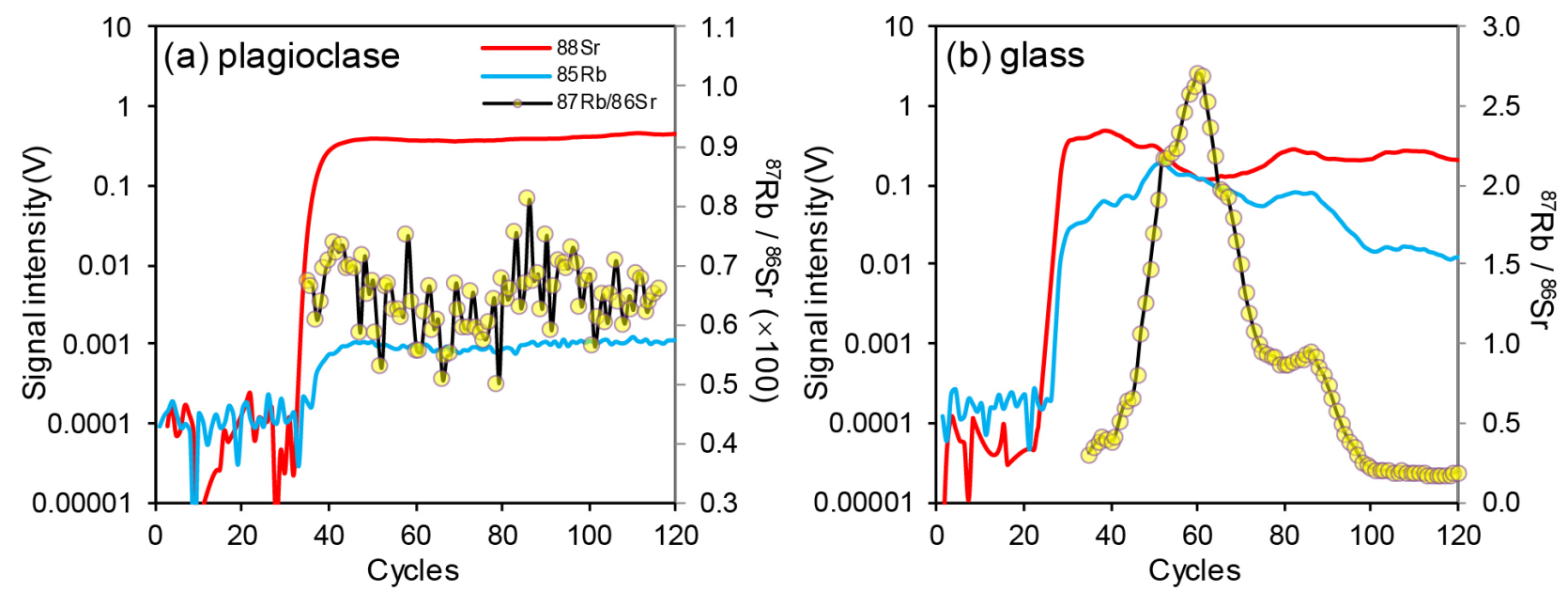

Fig. 4 The typical signal profiles of ${ }^{88} \mathrm{Sr},{ }^{85} \mathrm{Rb}$ and ${ }^{87} \mathrm{Rb} /{ }^{86} \mathrm{Sr}$ from the analyzed plagioclase (a) and glass (b) in lunar meteorites by LA-MC-ICP-MS.

error $=($ measured values $/$ recommended value -1$) \times 1000)$. When the ${ }^{87} \mathrm{Rb} /{ }^{86} \mathrm{Sr}$ ratio was higher than 1 , such as for NIST 610 $\left({ }^{87} \mathrm{Rb} /{ }^{86} \mathrm{Sr}=2.332\right)$, NIST $612\left({ }^{87} \mathrm{Rb} /{ }^{86} \mathrm{Sr}=1.181\right)$ and ATHO-G $\left({ }^{87} \mathrm{Rb} /{ }^{86} \mathrm{Sr}=2.021\right)$, large relative errors of more than $10 \%$ were obtained (Fig. 2a), implying that the Rb interference cannot be accurately corrected. For other reference materials with a ${ }^{87} \mathrm{Rb} /{ }^{86} \mathrm{Sr}$ ratio of less than 1 , relative errors of less than $0.2 \%$ were obtained, even when the $\mathrm{Sr}$ mass fractions were as low as $50 \mu \mathrm{g} \mathrm{g}^{-1}$ (HNB9, Fig $2 \mathrm{~b}$ and Table 2).

The repeated results of ${ }^{87} \mathrm{Rb} /{ }^{86} \mathrm{Sr}$ in the reference materials are shown in Table 2. The relative errors ((measured values / recommended value -1$) \times 100, \%$ ) in 11 glasses ranged from $3.46 \%$ to $2.89 \%$, independent of the $\mathrm{Sr}$ or $\mathrm{Rb}$ mass fractions. Therefore, the accuracy of ${ }^{87} \mathrm{Rb} /{ }^{86} \mathrm{Sr}$ in this study was about $3 \%$.

The repeatability of ${ }^{87} \mathrm{Sr} /{ }^{86} \mathrm{Sr}$ and ${ }^{87} \mathrm{Rb} /{ }^{86} \mathrm{Sr}$ in an individual run was assessed by the standard error (SE):

$$
\begin{aligned}
& S D=\sqrt{\frac{\sum(X-\bar{x})^{2}}{n-1}} \\
& S E=\frac{S D}{\sqrt{n}}
\end{aligned}
$$

where SD is the standard deviation; $\mathrm{X}$ is the isotope ratio in each cycle, $\bar{x}$ is the mean value; $\mathrm{n}$ is the number of values in one individual run. Here, the SD and SE values with the confidence interval of $95 \%$ were called $U_{S D}$ and $U_{S E}$, respectively. $U_{S D}$ represents an estimate of the variability of the isotope ratios in one individual run. $U_{S E}$ represents the variation of the average value in one individual run. As shown in Fig 3a, both $U_{S D}$ and $U_{S E}$ of ${ }^{87} \mathrm{Sr} /{ }^{86} \mathrm{Sr}$ depended on the signal intensity of ${ }^{88} \mathrm{Sr}$. Therefore, we can estimate the precision of ${ }^{87} \mathrm{Sr} /{ }^{86} \mathrm{Sr}$ in unknown samples based on their signal intensity of ${ }^{88} \mathrm{Sr}$ and the regression lines from reference materials. The same rule can also be observed in the relationship between $U_{S D}$ and $U_{S E}$ of ${ }^{87} \mathrm{Rb} /{ }^{86} \mathrm{Sr}$ and the signal intensity of ${ }^{85} \mathrm{Rb}$ (Fig. 3b).

Based on the results of accuracy and precision from the measurements of the 14 reference materials, we designed a reasonable technical criterion to filter the undesirable data during actual sample analyses.

(a) The data of the ${ }^{87} \mathrm{Rb} /{ }^{86} \mathrm{Sr}$ ratio of more than 1 should be deleted due to invalid correction of the $\mathrm{Rb}$ interference.

(b) The data of the ${ }^{88} \mathrm{Sr}$ signal of less than $0.2 \mathrm{~V}$ should be discarded due to the poor precision of ${ }^{87} \mathrm{Sr} /{ }^{86} \mathrm{Sr}$.

\section{RESULTS AND DISCUSSION}

\section{The signal features of natural samples}

In this study, several techniques were used to ensure that the $\mathrm{Sr}$ signal intensity is high enough for precise measurements, such as line scan mode with a scan speed of $2-6 \mu \mathrm{m} \mathrm{s}^{-1}$, high ablation frequency with a laser pulse repetition rate of $10-30 \mathrm{~Hz}$, and large spot size of 50-60 $\mu \mathrm{m}$. The typical laser ablation craters are shown in Fig. S2. Two different types of signal profiles were observed during the analyses of the natural minerals in the meteorites. In the first type, the $\mathrm{Sr}$ and $\mathrm{Rb}$ signal profiles are stable, indicating the homogenous distribution of $\mathrm{Sr}$ and $\mathrm{Rb}$ in the ablated area (Fig. 4a). Then, high precision of ${ }^{87} \mathrm{Rb} /{ }^{86} \mathrm{Sr}$ can be obtained. By contrast, dramatic fluctuations of the $\mathrm{Sr}$ and $\mathrm{Rb}$ signals occurred in the second type during the laser ablation process, resulting in the obvious variation of ${ }^{87} \mathrm{Rb} /{ }^{86} \mathrm{Sr}$ by more than one order of magnitude (Fig. 4b). This phenomenon could be attributed to the heterogeneous distribution of the $\mathrm{Sr}$ and $\mathrm{Rb}$ concentrations. The obtained ${ }^{87} \mathrm{Rb} /{ }^{86} \mathrm{Sr}$ ratio is inaccurate and has poor precision when 


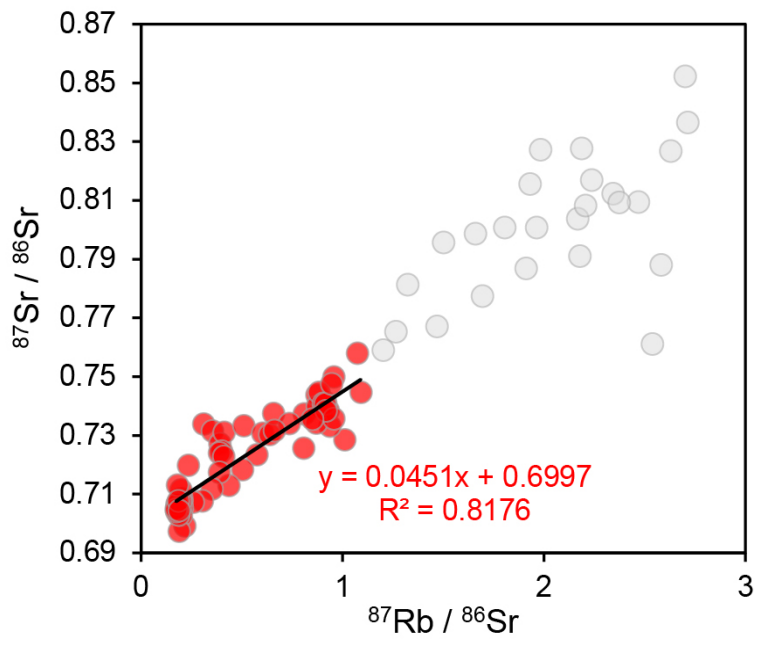

Fig. 5 The plot of ${ }^{87} \mathrm{Rb} /{ }^{86} \mathrm{Sr}$ versus ${ }^{87} \mathrm{Sr} /{ }^{86} \mathrm{Sr}$ for the data from Fig. 4(b).

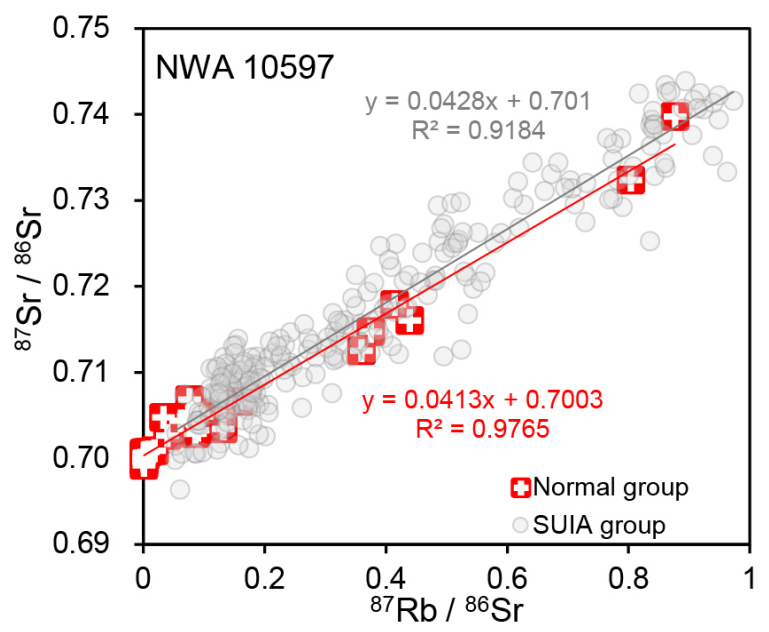

normal data reduction was used to calculate the ${ }^{87} \mathrm{Rb} /{ }^{86} \mathrm{Sr}$ ratio. Unfortunately, in the analyses of the meteorites, the second signal profile type (Fig. 4b) appeared frequently in clinopyroxenes, ilmenites, and silicate glasses, which seriously affected the quality of ${ }^{87} \mathrm{Rb} /{ }^{86} \mathrm{Sr}$.

Here, we established a new data reduction strategy. The smallest unit of data stored in MC-ICP-MS was called cycle in an individual run. After the corrections of background, interference, mass fractionation of ${ }^{87} \mathrm{Sr} /{ }^{86} \mathrm{Sr}$, and the external standard of ${ }^{87} \mathrm{Rb} /{ }^{86} \mathrm{Sr}$ for each cycle, we can plot ${ }^{87} \mathrm{Rb} /{ }^{86} \mathrm{Sr}$ versus ${ }^{87} \mathrm{Sr} /{ }^{86} \mathrm{Sr}$ using all the cycles. For measurements with a large variation of the $\mathrm{Sr}$ and $\mathrm{Rb}$ signals, ${ }^{87} \mathrm{Rb} /{ }^{86} \mathrm{Sr}$ and ${ }^{87} \mathrm{Sr} /{ }^{86} \mathrm{Sr}$ had a good correlation. Fig. 5 shows a typical plot of ${ }^{87} \mathrm{Rb} /{ }^{86} \mathrm{Sr}$ versus ${ }^{87} \mathrm{Sr} /{ }^{86} \mathrm{Sr}$ (data from Fig. 4b). According to the technical criterion described above, data with ${ }^{87} \mathrm{Rb} /{ }^{86} \mathrm{Sr}$ higher than 1 were deleted. Then the remaining data formed a regression line with a slope of 0.0451 and an intercept of 0.6997. The slope then can be used to calculate the $\mathrm{Rb}-\mathrm{Sr}$ isochron age. Note that the data for each cycle do not have any uncertainty, which is unfavorable for calculating the isochron age. In order to resolve this problem, we assigned the uncertainties of ${ }^{87} \mathrm{Rb} /{ }^{86} \mathrm{Sr}$ and ${ }^{87} \mathrm{Sr} /{ }^{86} \mathrm{Sr}$ in each cycle based on the signal intensities of ${ }^{85} \mathrm{Rb}$ and ${ }^{88} \mathrm{Sr}$, respectively. The assignment criterion was based on the relationship between the uncertainties and the signal intensities obtained from the measurements in the 14 reference materials (Fig. 3). $U_{S E}$ represents the variation of the average value and cannot show the variation range of each cycle during one individual run. Therefore, we selected the regression equation of $U_{S D}$ versus signal intensity to estimate the uncertainty for each cycle. This data reduction method was called the smallest unit isochron age (SUIA).

Fig. 6 The plot of ${ }^{87} \mathrm{Rb} /{ }^{86} \mathrm{Sr}$ versus ${ }^{87} \mathrm{Sr} /{ }^{86} \mathrm{Sr}$ for the data of the Normal group $(\mathrm{n}=36)$ and the SUIA group $(\mathrm{n}=244)$ in the NWA 10597.
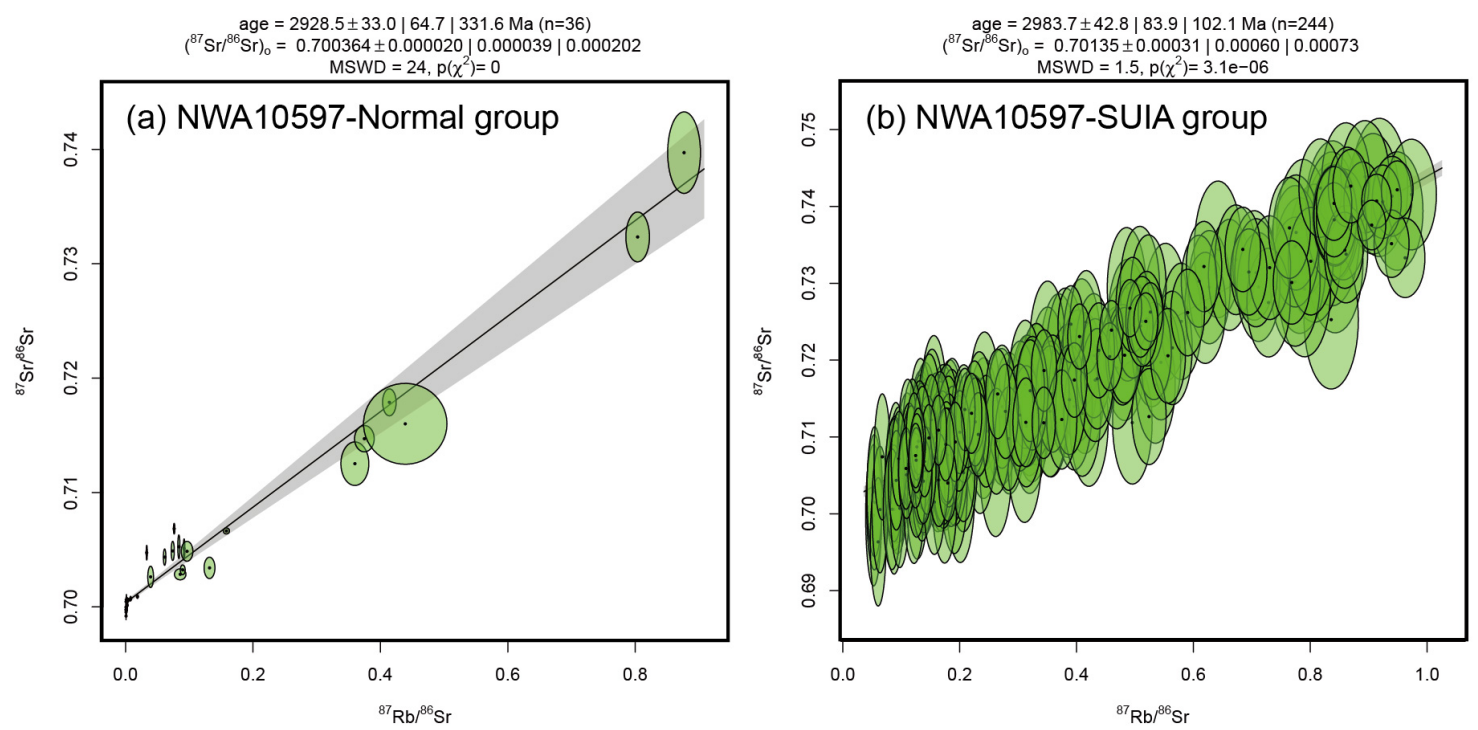

Fig. 7 The results of Rb-Sr isochron age calculated by IsoplotR for the data of the Normal group and the SUIA group in the NWA 10597 (a, b). 
Table 3 The calculation results of Rb-Sr isochron ages and initial ${ }^{87} \mathrm{Sr} /{ }^{86} \mathrm{Sr}$ by IsoplotR and Monte Carlo linear fitting for NWA 10597 and NWA 6950

\begin{tabular}{|c|c|c|c|c|c|c|c|c|c|c|c|}
\hline \multirow{3}{*}{ Samples } & & & \multicolumn{5}{|c|}{ Rb-Sr isochron age } & \multicolumn{4}{|c|}{ Initial ${ }^{87} \mathrm{Sr} /{ }^{86} \mathrm{Sr}$} \\
\hline & & & \multicolumn{3}{|c|}{ IsoplotR } & \multirow{2}{*}{$\begin{array}{l}\text { Monte Carlo } \\
\text { Linear Fitting }\end{array}$} & \multirow[b]{2}{*}{ Uncertainty } & \multicolumn{2}{|c|}{ IsoplotR } & \multirow{2}{*}{$\begin{array}{l}\text { Monte Carlo } \\
\text { Linear Fitting }\end{array}$} & \multirow[b]{2}{*}{ Uncertainty } \\
\hline & & & $\begin{array}{l}\text { Maximum } \\
\text { likelihood }\end{array}$ & Uncertainty & MSWD & & & $\begin{array}{l}\text { Maximum } \\
\text { likelihood }\end{array}$ & Uncertainty & & \\
\hline NWA & Normal group & $\mathrm{n}=36$ & 2929 & 33 & 24 & 2892 & 9 & 0.70036 & 0.00002 & 0.70033 & 0.00011 \\
\hline 10597 & SUIA group & $\mathrm{n}=244$ & 2984 & 43 & 1.5 & 2995 & 9 & 0.70135 & 0.00031 & 0.70098 & 0.00060 \\
\hline NWA & Normal group & $\mathrm{n}=70$ & 2507 & 33 & 21 & 2498 & 8 & 0.70380 & 0.00004 & 0.70352 & 0.00007 \\
\hline 6950 & SUIA group & $\mathrm{n}=986$ & 3149 & 20 & 1.5 & 3153 & 11 & 0.70281 & 0.00008 & 0.70252 & 0.00012 \\
\hline
\end{tabular}
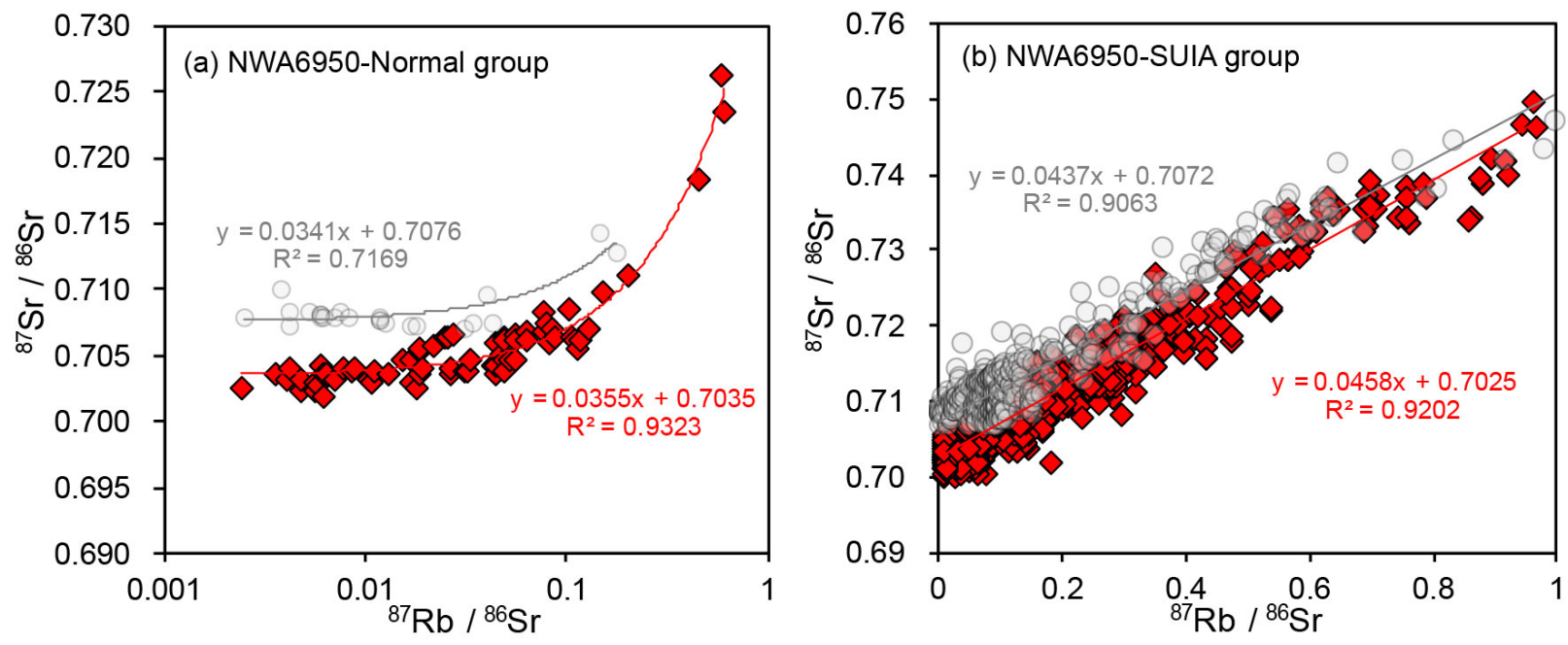

Fig. 8 The plot of ${ }^{87} \mathrm{Rb}^{86} \mathrm{Sr} v{ }^{87} \mathrm{Sr}{ }^{86} \mathrm{Sr}$ for the data of the Normal group (a) and the SUIA group (b) in the NWA 6950.

\section{The $\mathbf{R b}-\mathrm{Sr}$ isochron age for meteorites}

The minerals and glasses in the two meteorites were measured to determine the $\mathrm{Rb}-\mathrm{Sr}$ isochron age. The normal data reduction and SUIA were used to process the different types of the signal profiles. Below we will introduce and discuss the isochron age results in the two meteorites.

NWA 10597. The plagioclases, pyroxenes, and ilmenites in NWA 10597 were measured randomly. Thirty-six individual runs showed stable $\mathrm{Sr}$ and $\mathrm{Rb}$ signal intensities, leading to good analytical precisions. Therefore, these data were processed using the normal correction method and called Normal group. At the plot of ${ }^{87} \mathrm{Rb} /{ }^{86} \mathrm{Sr}$ versus ${ }^{87} \mathrm{Sr} /{ }^{86} \mathrm{Sr}$ (Fig. 6), the regression line in the Normal group has a slope of 0.0413 , an intercept of 0.7003 and a correlation coefficient of $0.9465\left(\mathrm{R}^{2}\right)$. On the other hand, six individual runs showed large variations of ${ }^{87} \mathrm{Rb} /{ }^{86} \mathrm{Sr}$, and were processed by the SUIA. In total, 244 cycles were obtained and called the SUIA group. As shown in Fig. 6, the SUIA group data also yielded a good regression line, with a slope of 0.0417 , an intercept of 0.701 and a correlation coefficient of $0.9126\left(\mathrm{R}^{2}\right)$. The data of the Normal group and the SUIA group are listed in Table $\mathrm{S} 1$. IsoplotR was used to calculate the $\mathrm{Rb}-\mathrm{Sr}$ isochron ages. ${ }^{35}$ The $\mathrm{Rb}-\mathrm{Sr}$ isochron age of the Normal group was $2928.5 \pm 33.0 \mathrm{Ma}$ (Fig. 7a), which is like the ${ }^{207} \mathrm{~Pb} /{ }^{206} \mathrm{~Pb}$ age of $3005 \pm 5 \mathrm{Ma}$ obtained from baddeleyites and zirconolites and the ${ }^{207} \mathrm{~Pb} / 206 \mathrm{~Pb}$ age of 3031 \pm 9 Ma obtained from apatites. ${ }^{29}$ However, the MSWD of 24 was high, indicating the large dispersion in the Normal group's data, especially for the data with ${ }^{87} \mathrm{Rb} /{ }^{86} \mathrm{Sr}$ ranging from 0.05 to 0.15 . These data generally were measured in pyroxenes. The $\mathrm{Rb}-\mathrm{Sr}$ isochron age of the SUIA group was 2983.7.5 \pm 42.8 Ma with a small MSWD of 1.5 (Fig. 7b). The result indicated that the assigned uncertainties of ${ }^{87} \mathrm{Rb} /{ }^{86} \mathrm{Sr}$ and ${ }^{87} \mathrm{Sr} /{ }^{86} \mathrm{Sr}$ for each cycle were reasonable. In addition, the Monte Carlo method was used to fit the regression line (simulation of 10,000 times). The fitted slopes were used to calculate the $\mathrm{Rb}$-Sr isochron age by using the isochron dating equation. The age results from the Monte Carlo linear fitting were $2892 \pm 9 \mathrm{Ma}$ and $2995 \pm 9 \mathrm{Ma}$ for the Normal group and the SUIA group, respectively (Table 3), which is consistent with those from IsoplotR. However, the age uncertainties from Monte Carlo linear fitting are obviously smaller than those from IsoplotR. In addition, IsoplotR and Monte Carlo linear fitting gave similar initial ${ }^{87} \mathrm{Sr} /{ }^{86} \mathrm{Sr}$ ratios.

NWA 6950. The plagioclases, pyroxenes, ilmenites, and glasses in NWA 6950 were measured. Ninety-four individual runs showed stable $\mathrm{Sr}$ and $\mathrm{Rb}$ signal intensities and were classified into the Normal group. Twenty-one individual runs were processed by the SUIA group. In both groups, two different regression lines were 

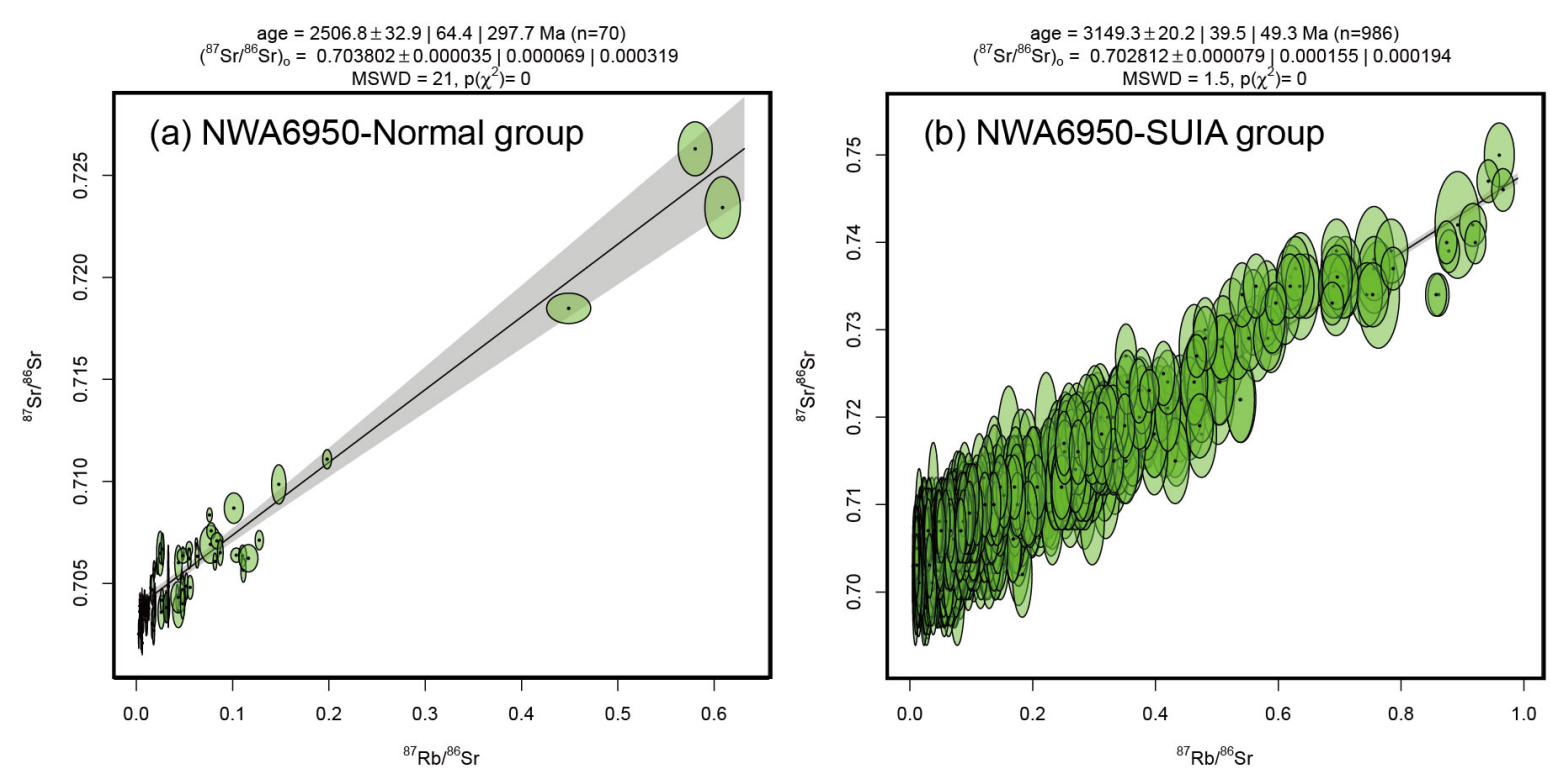

Fig. 9 The results of Rb-Sr isochron age calculated by IsoplotR for the data of the Normal group and the SUIA group in the NWA 6950 (a, b).

observed (Fig. 8). For example, 70 data in the Normal group gave a regression line with a slope of 0.0355 and an intercept of 0.7035 , but the other line from the remaining 24 data had a slope of 0.0341 and an intercept of 0.7076 . The SUIA group also showed a similar feature, including a line (986 cycles) with a slope of 0.0458 and an intercept of 0.7025 , and the other line (326 cycles) with a slope of 0.0437 and an intercept of 0.7072 . Most of the data with high initial ${ }^{87} \mathrm{Sr} /{ }^{86} \mathrm{Sr}$ (0.7072-0.7076) were measurements obtained for the glasses and pyroxenes in or around the black veins (Fig. S1). They are interpreted to have been affected by later geological processes. Therefore, we only kept the data with the initial ${ }^{87} \mathrm{Sr} /{ }^{86} \mathrm{Sr}$ around $0.703(0.7025-0.7035)$, and used IsoplotR and Monte Carlo linear fitting to calculate the $\mathrm{Rr}-\mathrm{Sr}$ isochron age.

The data of the Normal group and the SUIA group are listed in Table S2. Fig. 9a and 9b show the IsoplotR results. The Rb-Sr isochron ages of the Normal group and the SUIA group were $2506.8 \pm 32.9$ Ma with MSWD of 21 and $3149.3 \pm 20.2$ Ma with MSWD of 1.5, respectively. The $\mathrm{Rb}-\mathrm{Sr}$ isochron ages calculated by Monte Carlo linear fitting were $2498 \pm 8 \mathrm{Ma}$ and $3153 \pm 11 \mathrm{Ma}$ for the Normal group and the SUIA group, respectively. The Rb$\mathrm{Sr}$ isochron age of the Normal group is obviously younger than that of the SUIA group and the U-Pb ages of $3187 \pm 18 \mathrm{Ma}$ and $3120 \pm 18$ Ma obtained from baddeleyite and phosphate by SIMS. The younger age in the Normal group is attributed to the narrow range of ${ }^{87} \mathrm{Rb} /{ }^{86} \mathrm{Sr}$, which is mainly from 0.01 to 0.1 . We found that plagioclases and pyroxenes generally had low and stable ${ }^{87} \mathrm{Rb} /{ }^{86} \mathrm{Sr}$, while glasses and ilmenites had high and scattered ${ }^{87} \mathrm{Rb} /{ }^{86} \mathrm{Sr}$. Therefore, the Normal group was mainly made up of data with low ${ }^{87} \mathrm{Rb} /{ }^{86} \mathrm{Sr}$ ratios. By contrast, data in the SUIA group mainly had high ${ }^{87} \mathrm{Rb} /{ }^{86} \mathrm{Sr}$ ratios (up to 1 ) and provided better estimation of the $\mathrm{Rb}-\mathrm{Sr}$ isochron age.

\section{CONCLUSION}

In this study, an in situ $\mathrm{Rb}-\mathrm{Sr}$ dating method for different lunar meteorites using LA-MC-ICP-MS was established. Based on the analytical results from many reference materials, we suggested that the isobaric interference of ${ }^{87} \mathrm{Rb}$ on ${ }^{87} \mathrm{Sr}$ can be corrected by using the mathematical calculation for the sample if the ${ }^{87} \mathrm{Rb} /{ }^{86} \mathrm{Sr}$ is lower than 1. Under this prerequisite, the accuracy of ${ }^{87} \mathrm{Sr} /{ }^{86} \mathrm{Sr}$ and ${ }^{87} \mathrm{Rb} /{ }^{86} \mathrm{Sr}$ in reference glasses, clinopyroxenes and anorthite was better than $0.2 \%$ and $3 \%$, respectively. A new data reduction of SUIA was developed to resolve the problem of the high variation of ${ }^{87} \mathrm{Rb} /{ }^{86} \mathrm{Sr}$ in natural samples. The smallest unit of data was corrected and summarized to calculate the isochron age. Using the new reduction method, the Rb-Sr isochron age of 2984 $\pm 43 \mathrm{Ma}$ for NWA 10597 and $3149 \pm 20 \mathrm{Ma}$ for NWA 6950 was determined. The age results are like the U-Pb dating ages (2990$3032 \mathrm{Ma}$ for NWA 10597 and 3210-3187 Ma for NWA 6950) obtained for baddeleyite and apatite by using SIMS. The analytical results suggest that the in situ $\mathrm{Rb}-\mathrm{Sr}$ dating method presented in this study can be used to determine the age of lunar meteorites. Compared to the small and rare baddeleyites and apatites in meteorites, the targets for in situ $\mathrm{Rb}-\mathrm{Sr}$ dating can be the main component phases of different planetary materials.

Compared to ICP-MS/MS (such as with the Agilent 8800) or MC-ICP-MS with collision cell, the present method cannot measure ${ }^{87} \mathrm{Sr} /{ }^{86} \mathrm{Sr}$ in the $\mathrm{Rb}$-rich sample with an ${ }^{87} \mathrm{Rb} /{ }^{86} \mathrm{Sr}$ ratio $>$ 1 , which limits the application for young geological samples. However, when the main constituent phases (plagioclase, pyroxene, and glass) in old meteorites are targeted and measured, the present method provides higher analytical precision and 
accuracy for ${ }^{87} \mathrm{Sr} /{ }^{86} \mathrm{Sr}$ isotope analysis as compared with ICPMS/MS analysis. The MC-ICP-MS instrument with collision cell can resolve the interference of ${ }^{87} \mathrm{Rb}$ and provides excellent ${ }^{87} \mathrm{Sr} /{ }^{86} \mathrm{Sr}$ data. However, it is a new mass spectrometry system, very expensive, and thus increases the cost of analysis. Its popularity is still low in the global market.

\section{ASSOCIATED CONTENT}

The supporting information (Figs S1-S2; Tables S1-S2) is available at www.at-spectrosc.com/as/home

\section{AUTHOR INFORMATION}

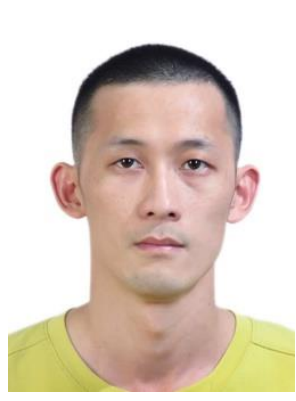

Wen Zhang is an associate professor at State Key Laboratory of Geological Processes and Mineral Resources, China University of Geosciences, Wuhan. He received the doctor of geochemistry degree from China University of Geosciences (Wuhan) in 2015. His research interests primarily focus on: 1) the in situ isotope ratio analysis using LAMC-ICP-MS, such as S-Cu-Fe-Zr-Sr-Nd-Hf$\mathrm{Pb}, 2)$ the development of the preparation process for quantitative analysis of major and trace elements, 3) the synthesis reference materials for elements and isotope ratios analysis using LA-ICP-MS. He has published over 60 peer-reviewed scientific papers in ISI-indexed journals, including Analytical Chemistry, Atomic Spectroscopy, Chemical Geology, Geostandards and Geoanalytical Research, Analytica Chimica Acta, and Journal of Analytical Atomic Spectrometry.

\section{Corresponding Author}

*W. Zhang

Email address: tuyaken@hotmail.com

Notes

The authors declare no competing financial interest.

\section{ACKNOWLEDGMENTS}

This research is supported by the pre-research project for Civil Aerospace Technologies funded by CNSA (D020205), the National Natural Science Foundation of China (41973013), the Natural Science Foundation of Hubei Province (2020CFA045), and the most special fund from the State Key Laboratory of Geological Processes and Mineral Resources, China University of Geosciences (MSFGPMR04 and MSFGPMR08).

\section{REFERENCES}

1. O. Hahn and E. Wallig, Z. Anorg. Allg. Chem., 1938, 236, 78-82. https://doi.org/10.1002/zaac.19382360109
2. O. Hahn, F. Strassman, J. Mattauch, and H. Ewald, Chem. Ztg., 1943, 67, 55-56.

3. O. Nebel, E. E. Scherer, and K. Mezger, Earth Planet. Sci. Lett., 2011, 301, 1-8. https://doi.org/10.1016/j.epsl.2010.11.004

4. A. M. Borst, T. E. Waight, A. A. Finch, M. Storey, and P. J. L. Roux, Lithos, 2019, 324-325, 74-88. https://doi.org/10.1016/j.lithos.2018.10.037

5. A. Julian, B. Michael, and I. S. Nugroho, Lithos, 2021, 388-389, 105971-105991. https://doi.org/10.1016/j.lithos.2021.105971

6. S. Lu, Y. Ren, Y. Hao, H. Hou, and Q. Yang, Ore Geol. Rev., 2021, 137,104295-104307. https://doi.org/10.1016/j.oregeorev.2021.104295

7. T. Zack and K. J. Hogmalm, Chem. Geol., 2016, 437, 120-133. https://doi.org/10.1016/j.chemgeo.2016.05.027

8. G. F. Zellmer, J. I. Kimura, Q. Chang, J. G. Shellnutt, M. Sas, and P. Shane, Lithos, 2018, 314-315, 52-58. https://doi.org/10.1016/j.lithos.2018.05.024

9. S. S. Li, M. Santosh, J. Farkaš, A. Redaa, S. Ganguly, S. W. Kim, C. Zhang, S. Gilbert, and T. Zack, Precambrian Res., 2020, 343, 105709-105715. https://doi.org/10.1016/j.precamres.2020.105709

10. M. Tillberg, H. Drake, T. Zack, E. Kooijman, M. J. Whitehouse, and M. E. Åström, Sci. Rep-UK, 2020, 10, 562-575. https://doi.org/10.1038/s41598-019-57262-5

11. Y. B. Zhu, T. Ariga, K. Nakano, and Y. Shikamori, At. Spectrosc., 2021, 42, 299-309. 10.46770/AS.2021.710

12. G. Craig, H. Wehrs, D. G. Bevan, M. Pfeifer, J. Lewis, C. D. Coath, T. Elliott, C. Huang, N. S. Lloyd, and J. B. Schwieters, Anal. Chem., 2021, 93, 10519-10527. https://pubs.acs.org/doi/10.1021/acs.analchem.1c01475

13. W. Zhang, Z. C. Hu, Y. S. Liu, T. Wu, X. D. Deng, J. L. Guo, and H. Zhao, Chem. Geol., 2018, 479, 10-21. https://doi.org/10.1016/j.chemgeo.2017.12.018

14. T. Kleine and J. F. Rudge, Elements, 2011, 7, 41-46. https://doi.org/10.2113/gselements.7.1.41

15. Y. Amelin and T. R. Ireland, Elements, 2013, 9, 39-44. https://doi.org/10.2113/gselements.9.1.39

16. K. Rankenburg, A. D. Brandon, and M. D. Norman, Geochim. Cosmochim. Acta, 2007, 71, 2120-2135. https://doi.org/10.1016/j.gca.2007.01.014

17. K. Misawa, M. Tatsumoto, G. B. Dalrymple, and K. Yanai, Geochim. Cosmochim. Acta, 1993, 57, 4687-4702. https://doi.org/10.1016/0016-7037(93)90193-Z

18. X. Che, A. Nemchin, D. Liu, T. Long, C. Wang, M. D. Norman, K. H. Joy, R. Tartese, J. Head, B. Jolliff, J. F. Snape, C. R. Neal, M. J. Whitehouse, C. Crow, G. Benedix, F. Jourdan, Z. Yang, C. Yang, J. Liu, S. Xie, Z. Bao, R. Fan, D. Li, Z. Li, and S. G. Webb, Science, 2021, 374, 887-890. https://doi.org/10.1126/science.abl7957

19. Q. L. Li, Q. Zhou, Y. Liu, Z. Y. Xiao, Y. T. Lin, J. H. Li, H. X. Ma, G. Q. Tang, S. Guo, X. Tang, J. Y. Yuan, J. Li, F. Y. Wu, Z. Y. Ouyang, C. L. Li, and X. H. Li, Nature, 2021, 600, 54-58. https://doi.org/10.1038/s41586-021-04100-2

20. Z. C. Hu, W. Zhang, Y. S. Liu, S. Gao, M. Li, K. Q. Zong, H. H. Chen, and S. H. Hu, Anal. Chem., 2015, 87, 1152-1157. https://pubs.acs.org/doi/10.1021/ac503749k

21. K. P. Jochum, U. Weis, B. Stoll, D. V. Kuzmin, Q. Yang, I. Raczek, D. E. Jacob, A. Stracke, K. Birbaum, D. A. Frick, D. Günther, and J. Enzweiler, Geostand. Geoanal. Res., 2011, 35, 397-429. https://doi.org/10.1111/j.1751-908X.2011.00120.x 
22. K. P. Jochum, B. Stoll, K. Herwig, M. Willbold, A. W. Hofmann, M. Amini, S. Aarburg, W. Abouchami, E. Hellebrand, and B. Mocek, Geochem. Geophy. Geosy., 2006, 7, 1-44. https://doi.org/10.1029/2005GC001060

23. K. P. Jochum, M. Willbold, I. Raczek, B. Stoll, and K. Herwig, Geostand. Geoanal. Res., 2005, 29, 285-302. https://doi.org/10.1111/j.1751-908X.2005.tb00901.x

24. M. Elburg, P. Vroon, B. van der Wagt, and A. Tchalikian, Chem. Geol., 2005, 223, 196-207. https://doi.org/10.1016/j.chemgeo.2005.07.001

25. H. Zhao, X.-M. Zhao, P. J. Le Roux, W. Zhang, H. Wang, L.-W. Xie, C. Huang, S.-T. Wu, J.-H. Yang, F.-Y. Wu, and Y.-H. Yang, Front. Chem., 2020, 8, 594316-594329. https://doi.org/10.3389/fchem.2020.594316

26. X. R. Tong, Y. S. Liu, Z. C. Hu, H. H. Chen, L. Zhou, Q. H. Hu, R. Xu, L. X. Deng, C. F. Chen, L. Yang, and S. Gao, Geostand. Geoanal. Res., 2016, 40, 85-99. https://doi.org/10.1111/j.1751-908X.2015.00315.x

27. J. D. Woodhead and J. M. Hergt, Geostand. News., 2001, 25, 261-266. https://doi.org/10.1111/j.1751-908X.2001.tb00601.x

28. K. P. Jochum, S. A. Wilson, W. Abouchami, M. Amini, J. Chmeleff, A. Eisenhauer, E. Hegner, L. M. Iaccheri, B. Kieffer, J. Krause,
W. F. McDonough, R. Mertz-Kraus, I. Raczek, R. L. Rudnick, D. Scholz, G. Steinhoefel, B. Stoll, A. Stracke, S. Tonarini, D. Weis, U. Weis, and J. D. Woodhead, Geostand. Geoanal. Res., 2011, 35, 193-226. https://doi.org/10.1111/j.1751-908X.2010.00114.x

29. Y. Wu and W. Hsu, Icarus, 2020, 338, 113531-113545. https://doi.org/10.1016/j.icarus.2019.113531

30. A. Bouvier, J. Gattacceca, J. Grossman, and K. Metzler, Meteorit. Planet. Sci., 2017, 52, 2411. https://doi.org/10.1111/maps.12944

31. Q. He, L. Xiao, B. Ioannis, X. C. Che, Y. Q. Qian, and J. W. J. Zhao, J. Geophys. Res., 2022, In Press.

32. W. Zhang, Z. C. Hu, and Y. S. Liu, J. Anal. At., Spectrom., 2020, 35, 1087-1096. https://doi.org/10.1039/D0JA00084A

33. K. P. Jochum, B. Stoll, U. Weis, D. V. Kuzmin, and A. V. Sobolev, J. Anal. At. Spectrom., 2009, 24, 1237-1243. https://doi.org/10.1039/B905045K

34. W. A. Russell, D. A. Papanastassiou, and T. A. Tombrello, Geochim. Cosmochim. Acta, 1978, 42, 1075-1090. https://doi.org/10.1016/0016-7037(78)90105-9

35. P. Vermeesch, Geosci. Front., 2018, 9, 1479-1493. https://doi.org/10.1016/j.gsf.2018.04.001 